\title{
Review
}

\section{Research trends in obesity \& obesogenic environments in Korea}

\author{
Myoungsook Lee ${ }^{\S}$ \\ Department of Food and Nutrition \& Research Institute of Obesity Sciences, Sungshin Women's University, 76ga- 55, Dobong-ro, Gangbuk-gu, Soeul 01133, Republic \\ of Korea
}

BACKGROUND/OBJECTIVES: Globally, it has been projected that there will be 2 billion overweight and 1 billion obese individuals by 2030. In Korea, the prevalence of adult obesity (BMI > 25) increased from $29.7 \%$ in 2009 to $32.4 \%$ in 2015 . Moreover, childhood obesity, which leads to adulthood obesity, has increasingly become a social problem. The purpose of this review is to summarize the scientific basis for the development of effective models and policies aimed at preventing obesity over a lifetime based on research modeling obesogenic environments.

MATERIALS/METHODS: The review focuses on the characteristics of obesity prevalence and trends in 3P analysis (papers, patents, and products) as well as government-funded projects in Korean obesity obesogenic environments over the last 10 years. RESULTS AND DISCUSSION: As a result of the $3 \mathrm{P}$ analysis, studies on obesity risk factors were frequently carried out, according to two data bases RISS (4.9\%) and PubMed (24.7\%). Since there were only $17 \%$ patents related to the mechanism of preventing obesity in 7,951 Korean patents related to obesity, new paradigms of technologies to dominate the global obesity markets are needed. After government-funded projects were analyzed, communication and cooperation in multi-governmental departments were suggested to elucidate the characteristics of Korean obesity. Government should also produce short- and long-term road maps to develop a practical, successful outcome. Although the rate of obesity in Korea is currently lower than in other developed countries according to WHO criteria, without adequate governmental intervention, obesity rates will approach those of the top countries with high incidence rates of obesity within the next 10 years.

Nutrition Research and Practice 2019;13(6):461-472; https://doi.org/10.4162/nrp.2019.13.6.461; pISSN 1976-1457 elSSN 2005-6168

Keywords: Systematic review, obesogenic environment, 3P analysis, obesity research modeling

\section{INTRODUCTION}

Globally, it has been projected that there will be two billion overweight and one billion obese individuals by 2030 . The phenomenon of obesity is unique and distributed from childhood to old age. According to Organization for Economic Cooperation and Development (OECD) data, the adult obesity rate has increased steadily since 1990, with an average of $19.5 \%$, led by the US and Mexico at $38.2 \%$ and $32.4 \%$, with lower rates of $3.7 \%$ and $5.3 \%$ for Japan and Korea, respecively (Fig. 1) [1].

Unlike the OECD standard, Korea defines obesity as BMI > 25 , and the prevalence of adult obesity increased from $29.7 \%$ in 2009 to $32.4 \%$ in 2015 . Abdominal obesity, based on waist circumference (male; $\geq 90 \mathrm{~cm}$, female; $\geq 85 \mathrm{~cm}$ ), increased from $18.4 \%$ in 2009 to $20.8 \%$ in 2015 [2,3]. From 2014 to 2015 , males were dominant over females from the ages of 20 to 60 years and women were dominant from 65 years old on. In particular, between the ages of 35 to 39 years, $45.3 \%$ of men were obese compared to $17.3 \%$ of women. While severely obese men (BMI $>30$ ) aged 20 to 49 years outnumbered women by $3.4 \%$ to $4.05 \%$, there were more severely obese women aged 70 or older compared to men, and extreme obesity $(\mathrm{BMI}>35)$ followed the same age patterns [4].

In the past, the rate of obesity among Korean adults in the OECD was low. However, the prevalence of childhood obesity recently increased from $11.6 \%$ to $15.6 \%$ over 10 years from 2006 to 2015 [5]. The number of people with low-risk obesity increased 1.2 times, that of moderate-risk obesity 1.4 times, and that of high-risk obesity doubled. In particular, 1 out of 4 (25\%) male Korean children aged 5 to 17 years old are currently obese, a rate higher than the OECD average of $23 \%$ [6]. Currently, it is difficult to determine the cause of Korean childhood obesity since most pediatric obesity studies are only cross-sectional in design and there is a lack of intervention studies. The recent finding that $74.7 \%$ of adult diabetes patients are obese (abdominal obesity) is also related to the fact that more than $70 \%$ of childhood obesity under the age of 7 years persist into adulthood, indicating the incidence of obesity combined with diabetes. Therefore, it is urgent to develop a better understanding of the specific risk factors of obesity at each lifecycle stage [7].

In 2015, 4 million people died from obesity, and their lives were shortened due to disability years of life lost (DYLL) [8]. In particular, $41.4 \%$ of obese people with BMl over 30 died due

\footnotetext{
This work was supported by a 2019 Sungshin Women's University Research Grant.

${ }^{\S}$ Corresponding Author: Myoungsook Lee, Tel. 82-2-920-7211, Fax. 82-2-920-2078, Email. mlee@sungshin.ac.kr

Received: July 17, 2019, Revised: August 22, 2019, Accepted: October 22, 2019

This is an Open Access article distributed under the terms of the Creative Commons Attribution Non-Commercial License (http://creativecommons.org/licenses/by-nc/3.0/) which permits unrestricted non-commercial use, distribution, and reproduction in any medium, provided the original work is properly cited.
} 


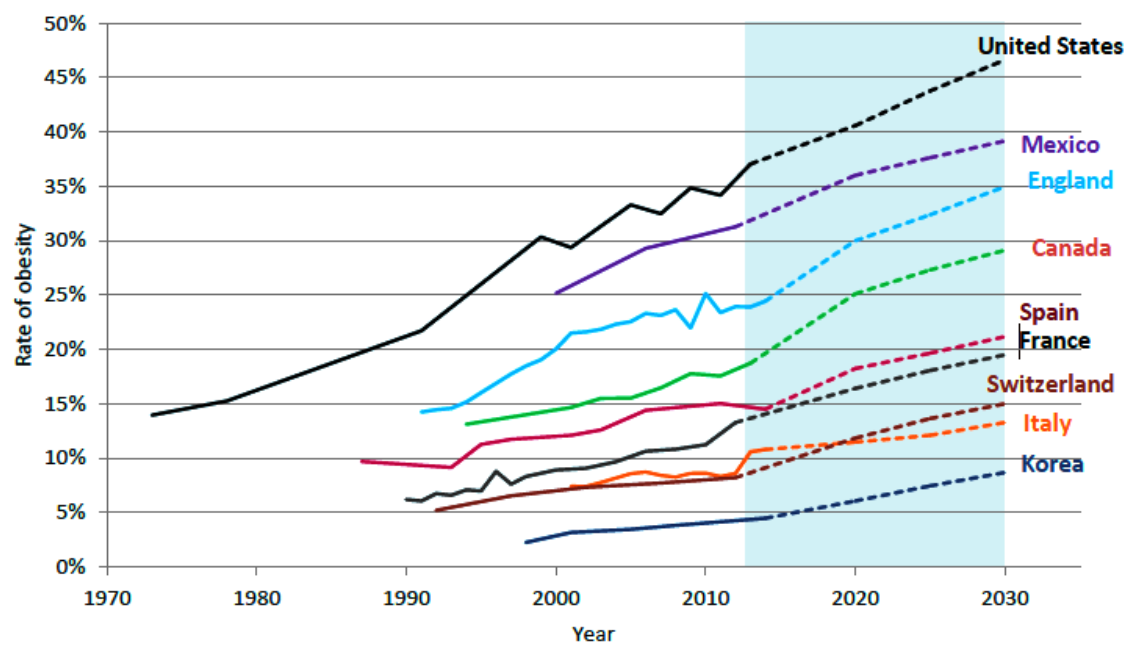

Fig. 1. OECD projections assuming that BMl will continue to rise as a linear function of time. Obesity was defined as BMl $>30 \mathrm{Kg} / \mathrm{m}^{2}$ in adults aged $15-74$ years. Age and gender-adjusted rates using the 2005 OECD standard population. Height and weight were measured in England, Hungry, Korea, Mexico, and the USA but self-reported in other countries, (From 2017 OECD analysis of national health survey data). (ref; 1)

to cardiovascular disease, $9.5 \%$ due to diabetes, and $4.7 \%$ due to kidney disease. According to the Cleveland Clinic Research Institute in the US, due to DYLL, obesity reduces life expectancy by more than $47 \%$ versus diabetes, smoking, and high blood pressure [9]. According to Korean National Health Insurance Service data, the social and economic costs for obesity prevention and treatment in Korea were about 4.7 trillion won in 2006 but doubled to 9.0 trillion won by $2016[10,11]$. Until recently, 27 raw materials were individually recognized for the purpose of body fat reduction by the Ministry of Food and Drug Safety, but sales of body fat reduction health functional foods constituted only 0.14 trillion won [12]. Sales were low since most of these functional raw materials depend on imports, making it difficult to predict increase in socioeconomic costs without domestic development of functional raw materials.

Analysis of the obesogenic environment of Koreans according to lifecycle can help reduce social and economic deficits in direct or indirect obesity prevention and treatment as well as provide basic data for fostering a healthy economy. We also hope that our findings will inform specific national policy proposals to prevent and manage obesity.

\section{MATERIALS AND METHODS}

To understand the trends in obesity research in Korea, three time periods (1984-1999, 2000-2015, and 2016 to the present) analyzed according to large events that changed research trends in obesity. These changes in research trends caused by three national or international events were categorized.

3P analysis (Papers, Patents, and Products) related to obesity studies were investigated. A total of 6,024 Korean papers were found in the Research Information Sharing Service (RISS) from 2008 to 2018, wherase international papers were divided into total obesity study papers, human body studies, or in vitro/in vivo research papers published in PubMed as well as studies on obesity prevalence rate, obesity incidence rate, risk factors, diet patterns, environmental factors, and anti-obesity materials.
Trends in obesity-related patents were analyzed by dividing them into health functional food patents (total 578 cases) and natural extract patents (total 266 cases) based on obesityrelated patents registered over 10 years from 2008 to 2018 [13]. From 2004 to 2018, a total of 33 functional fields were recognized by the Ministry of Food and Drug Safety (KFDA) as categories for functional materials, and a total of 664 raw materials were approved [14]. In particular, we analyzed preferred functionality when classifying health functional foods based on total sales in 2016. The purposes of this 3P research study are to help promote the study of obesity in Korea, reduce the number of obese people by identifying available technologies for the study of obesity, and suggest policies that should be supported by the country.

Using National Science \& Technology Information (NTIS) DB provided government-funded $R \& D$, obesity and obesogenic environmental projects focusing on national level research reports during the last 10 years were considered and compared to international cases. Consideration of the pros and cons of government-funded $R \& D$ is very important since they will be the foundation of future research models and policy suggestions. Since childhood obesity has reached alarming levels worldwide, multi-cooperative programs conducted in many developed countries were introduced. Based on our research environments, effective research modeling for obesity and customized nutrition according to lifecycle stage along with directionality of nutrition policy might finally be suggested.

\section{RESULTS AND DISCUSSION}

Events that changed research trends in obesity

Before analyzing trends in obesity research, we identified three big events that changed national research trends in obesity (1984-1999, 2000-2015, and 2016 to the present). The first event began in 1998, when the $\mathrm{NIH}$ and WHO designated obesity as a disease and prepared to collect scientific evidence and when Korea National Health and Nutrition Examination 


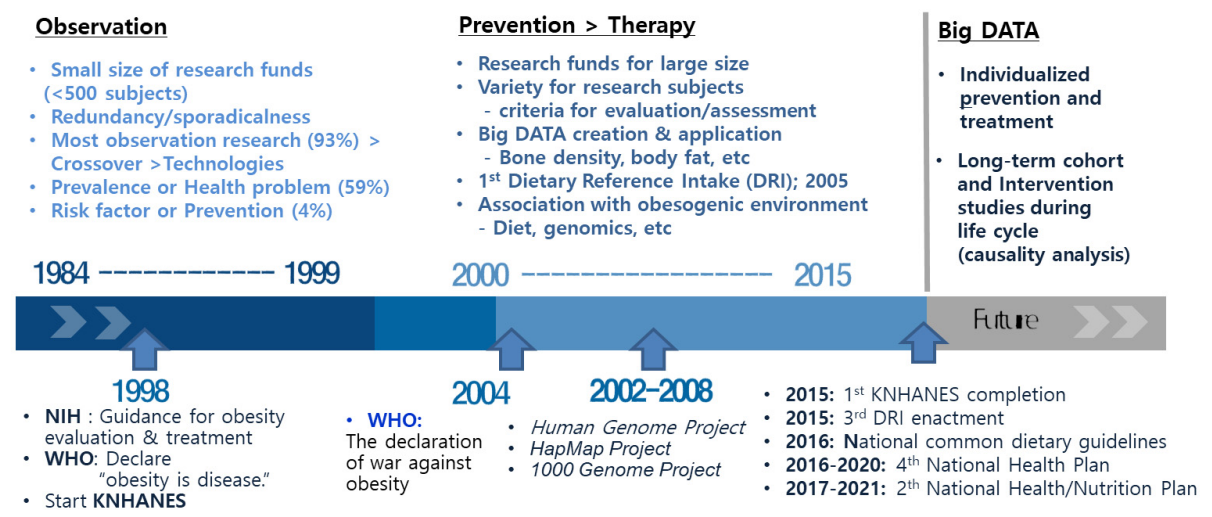

Fig. 2. Analysis of obesity research trends in Korea. Above the chronology bar, the trends and factors influencing obesity research are described, with milestones important to obesity research highlighted below the chronology bar.

Table 1. Research articles related to 'obesity' published from 2008 to 2018 in Korean and international journals

\begin{tabular}{|c|c|c|c|c|c|c|}
\hline \multirow{2}{*}{ Research Subjects } & \multicolumn{3}{|c|}{ RISS } & \multicolumn{3}{|c|}{ PubMed } \\
\hline & Total $\left(\mathrm{n}^{*}\right)$ & Human & In vitro \& In vivo & Total $\left(\mathrm{n}^{*}\right)$ & Human & In vitro \& In vivo \\
\hline Obesity prevalence rate & $203(11)$ & 203 & - & $330(65)$ & 330 & - \\
\hline Obesity incidence rate & $19(3)$ & 19 & - & $68(12)$ & 68 & - \\
\hline Risk factors ${ }^{1)}$ & $294(33)$ & 292 & 2 & $502(57)$ & 502 & - \\
\hline Dietary pattern & $16(2)$ & 15 & 1 & $30(3)$ & 30 & - \\
\hline Environmental factors ${ }^{2)}$ & $9(3)$ & 9 & 0 & 139 (19) & 66 & 73 \\
\hline Mechanism & $132(7)$ & 72 & 60 & $141(3)$ & 76 & 65 \\
\hline Functional base materials ${ }^{3)}$ & $218(0)$ & - & 218 & $97(0)$ & - & 97 \\
\hline Total cases & $6,024(629 *)$ & 5,650 & 374 & $2,036\left(281^{*}\right)$ & 1,827 & 209 \\
\hline
\end{tabular}

* Subject to children obesity

1) Common risk factors for obesity (BMI, WC, WHR, etc.) and obesity-related complexes such as diabetes mellitus, stress, depression and so on

2) Lifestyle, genetics, stress, exercise, food allergy, muscle weakness and so on

${ }^{3)}$ Assessment for functionality of product-specific health functional/natural food ingredients, microbiomes and so on

Survey (KNHANES) was launched. The second criterion, 2000-2015, was internationally separated in order to emphasize the time period focused on prevention rather than treatment for obesity, as the third DRI was enacted. The third event was initiated by the Fourth Industrial Revolution period along with the fourth KNHANES in 2016. These changes in research trends caused by three national or international events were categorized (Fig. 2). Obesity research on observation, crossover, and risk factors was performed before 2000. On the other hand, a variety of research methodologies, including statistics and subjects, focused on the creation of big data along with government support in the second stage. Through the Fourth Industrial Revolution, we will expect what or how these technologies such as application of big data, artificial intelligence techniques, and so on could be comprehensively applied into obesity research.

$3 P$ analysis of Korea obesity studies (papers, patents, and products)

According to an analysis of Korean research on obesity published from 2008 to 2018 using national RISS data $(6,024)$, there have been many papers on obesity risk factors $(n=294)$, anti-obesity materials $(n=218)$, obesity prevalence $(n=203)$, and obesity mechanisms $(n=132)$ (Table 1$)$. Based on international PubMed data $(n=2036)$, there have been numerous obesity papers published about obesity risk factors $(n=502)$, obesity prevalence $(n=330)$, obesity mechanisms $(n=132)$, and anti-obesity materials $(n=97)$. Among obesity papers, studies about obesity risk factors were frequently carried out, according to two databases, RISS ( $n=294,4.9 \%)$ and PubMed $(n=502$, $24.7 \%)$. Research on anti-obesity materials using in vitro/in vivo approaches was more frequently published in Korea $(n=218)$ than in international publications $(n=97)$, whereas research on clinical intervention for obesity risk factors was found to be lacking in Korea.

From 2004 to 2018, a total of 33 functional fields were recognized by the Ministry of Food and Drug Safety (KFDA) as categories for functional materials, and a total of 664 raw materials were approved (Fig. 3, Table 2). Among the functional categories classified in 2004, 91 raw materials were recognized by the body fat reduction (anti-obesity) field, followed by joint and bone health (61 cases) in second place and memory improvement and eye health (48 cases). In 2018, the most recently recognized functional area was muscle strength improvement, with only one material being approved. About $50 \%$ of the 7,951 Korean patents registered from 2008 to 2018 were for anti-obesity materials, and most of these were for functional raw materials related to body fat reduction (Fig. 4) $[13,14]$. However, $36 \%$ of registered anti-obesity material patents were for ingredients, and only $17 \%$ covered the mechanism. For materials, $79 \%$ were plants, $10 \%$ were animals, and $11 \%$ were microbes.For ingredients, 36\% were sugars, 32\% new 


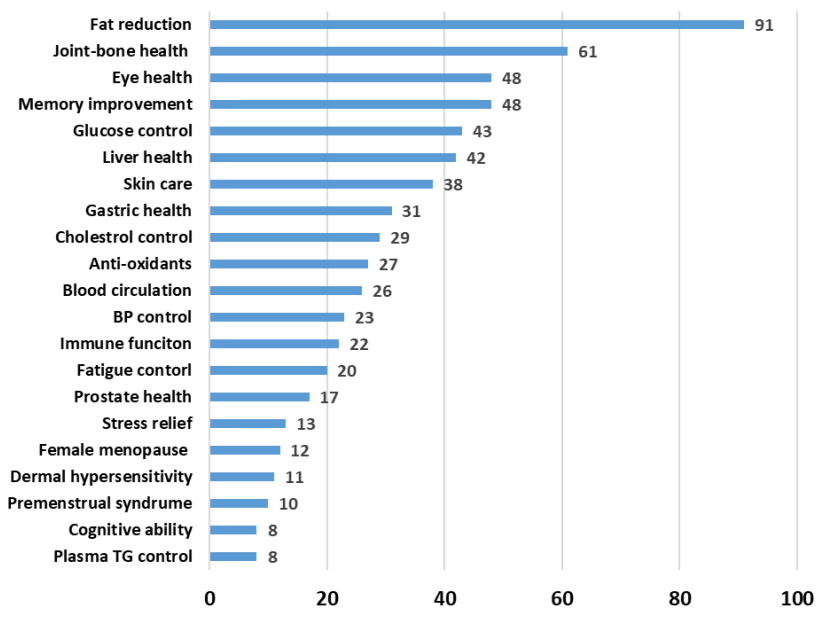

Fig. 3. Total cases of 664 base-materials approved by the KFDA through Oct $31^{\text {th }}$, 2018. The cases for reduction of fat $(91,13.7 \%)$ were largest, followed by joint health (61, $9.2 \%)$, eye health $(48,7.2 \%)$, and memory improvement $(48,7.2 \%)$.

Table 2. Individually approved raw materials for body fat reduction function [Criteria of the Ministry of Food and Drug Safety] (2018.10.31.)

\begin{tabular}{|c|c|}
\hline Functionality & Approved the raw material for functionalities ( 29 out of $91^{*}$ ) \\
\hline Fat reduction & $\begin{array}{l}\text { Garcinia Cambogia bark extract } \\
\text { Conjugated linoleic acid (Free Fatty Acid) } \\
\text { Conjugated linoleic acid (Triglyceride) } \\
\text { Green Mate extract } \\
\text { Green tea extract } \\
\text { Complex of soybean embryo extract } \\
\text { Lemon balm extract powder mixture } \\
\text { Medium chain fatty acid (MCFA) containing oil } \\
\text { Coloseus Foscoli extract } \\
\text { Hibiscus compound extract } \\
\text { Sesame leaf extract } \\
\text { L-carnitine tartrate } \\
\text { Vegetable oil diglycerides } \\
\text { Lactoferrin (Milk refining protein) } \\
\text { Lactobacillus gasseri BNR17 } \\
\text { Wild mango seed extract } \\
\text { Mate hot water extract } \\
\text { Chitooligosaccharide } \\
\text { Green coffee bean alcohol extract } \\
\text { Green coffee bean extract } \\
\text { Boi tea extract } \\
\text { Seaweed compound extract (Xanthigen) } \\
\text { Rhynchosia Nulubilis peptide complex } \\
\text { Boesenbergia pandurata extract powder } \\
\text { Chitosan } \\
\text { Fermented vinegar pomegranate complex } \\
\text { Green apple extract polyphenol (Applephenon) } \\
\text { Gynostemma pentaphyllum leaf alcohol extract powder } \\
\text { Cissus antarctica extract }\end{array}$ \\
\hline
\end{tabular}

* There are a total of 29 individually approved raw materials related to body fat reduction. However, a total of 91 are considered to be approved since they are based on the above 29 materials.

materials, $19 \%$ fats, and $13 \%$ proteins. Fifty-five percent of the mechanisms were related to the regulation of lipid absorption, and $45 \%$ were focused on digestion and appetite control (Fig. 4). An average of 873 cases were registered between 2009 and

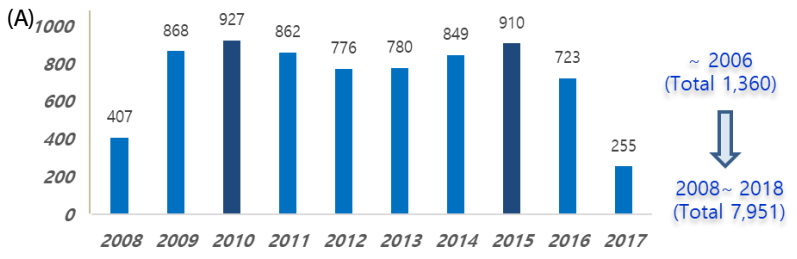

(B)

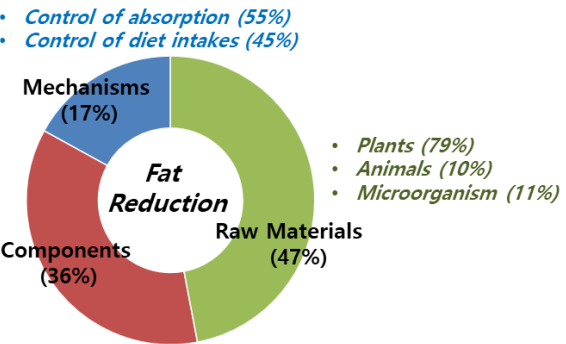

Fig. 4. Total cases of patent registration related to obesity for 10 years from 2008 to 2018 . The total number of cases was 8,000 , which was six times larger than before 2006. Except in 2008, 2016 and 2017, an average of 850 cases were registered every year. (A) Total patents related to fat reduction, most about raw materials (47\%), particularly plants, followed by components (36\%) and mechanisms (17\%) in order. (B) (This figure was manipulated from the original data of references, 13.14 \& 15)

2015 , but the number has decreased rapidly since 2016 . This decline can be attributed to the fact that those filing materialoriented patents often fail to commercialize the products. Thus it is likely that the commercialization of research requires more than just registering anti-obesity functional foods for practical use or utilization. A total of 538 patents have been registered as foods over the past decade, whereas a total of 251 patents have been registered as anti-obesity natural extract functional foods. Both types of patens have demonstrated their largest numbers for medicine and cosmetics, but both declined in 2015 when individual material-related patent registrations were low. In particular, international patents have been on a sharp decline since 2003, when 170 cases were registered. This reduction is a reflection of the changes in expectations for the healthfunctioning food market when the drug market faltered due to the withdrawal of the anti-obesity drug Reductil from the obesity market in 2010 [15].

This 3P analysis of obesity in Korea indicates that the formation of a new paradigm is necessary to develop natural material-based diet drugs for food and medicine. Existing anti-obesity mechanism technologies focus on the control of meals and limitation of energy absorption. Only the development of a new technology will overcome these limitations. For example, a new technology using exothermic reactions and increasing fatty acid oxidation to increase energy consumption will greatly affect the anti-obesity food and drug markets related to bio-sector paradigm formation.

\section{Analysis of obesity grant support trends by Korea and overseas institutions}

According to NTIS data from 2011 to 2104, among the 22 Korean ministries, the Ministry of Food and Drug Safety (85 cases), Ministry of Health and Welfare (53 cases), Ministry of Culture, Sports and Tourism (52 cases), Department of Education (36 cases), Ministry of Land, Infrastructure, and Transport (7 
cases), Ministry of Employment and Labor (6 cases), and the Department of the Environment ( 2 cases) conducted projects related to obesity prevention management, determinative factors of obesity, and health of the population [16].

No related white papers or business reports were identified for the Ministry of Gender Equality and Family and the Ministry of Agriculture, Food, and Rural Affairs during the survey period. Regarding major obesity-related projects, the Ministry of Health and Welfare has been supporting health and medical technology research and development projects since 1995 and has estabilished obesity prevention and management systems focusing on obesity, smoking, childhood, and youth obesity through the National Health Fund project [17]. Among obesity prevention and treatment programs, the Ministry of Food and Drug Safety has implemented a nutrition education program at the Centers for the Children's Food Service Management, the National Institutes of Health is responsible for the Chronic Disease Gene Project in Korea [18,19], the Rural Development Administration is supporting a project identifying the excellence of Korean food and the Next Generation Bio-green 21 Project, the Ministry of Science is supporting the Children's Youth Obesity Prevention Management Business Group, and the Ministry for Food, Agriculture, Forestry, and Fisheries is promoting high-value technology businesses and the New Biomaterials Center for Anti-Obesity (NBiCA).

In other developed countries, the US Federal Council is leading a multi-agency collaboration with the United States Department of Agriculture (USDA), United States Department of Health and Human Services (HHS), and United States Department of Defense (DoD) under a long-term roadmap that is composed of public-private partnerships among government, academic, and private organizations [20]. For example, the National Nutrition Roadmap for Obesity led by the Interagency Committee on Human Nutrition Research (ICHNR) in 2016-2021 has three primary goals: Q-1. How will you explain your understanding and definition of eating habits to improve and maintain your health? (Health Promotion - OMIX individual difference study); Q-2. What do you need to do to help people choose healthy eating patterns? (food pattern intervention, environmental system sustainability); Q-3. How can you develop and participate in innovative methods and systems to accelerate the discovery of human nutrition? (behavior habits-big data) $[21,22]$. A total of 107 related studies on obesity nutrition programs have been conducted by various gruops and administrative ogranizations, including Immunity and Disease Prevention Research, Obesity and Metabolism Research, Dietary Prevention Healthy Body Weight Research, Sugar Beet and Potato Research, the Children's Nutrition Research Center, Plant, Soil, and Nutrition Research, the Jean Mayer Human Nutrition Research Center On Aging, the Food Surveys Research Group, Nutrient Data Laboratory Diet, the Genomics and Immunology Laboratory, the Food Components and Health Laboratory, and the Food Composition and Methods Development Laboratory [23].

In Japan, the National Agricultural Research Organization (NARO) of the Ministry of Agriculture performs research related to improving the value and safety of agricultural products [24]. The National Institute of Health and Nutrition (NIHN) is in charge of the Department of Nutrition and metabolism as well as the addition of functional food labeling for new food labeling systems. In Australia, a national level National Obesity Taskforce was formed in 2003 and Healthy Weight 2008: Australia's Future was published in 2008 [25]. Since 2008, the National Health Priority Area has been established. In 2016, it was selected as one of nine priority health issues at the national level. In 2007, the UK Government Office for Science and Department of Health organized the Obesity System Map, which schematized the complex interrelationships and relative importance between various factors affecting obesity incidence through "Tracking Opportunities: Future Choices" [26]. It sought to conceptualize interdependencies among each factor within the entire system by providing the most comprehensive view in order to analyze relationships between major determinants and factors affecting the occurrence of obesity as well as to present policy alternatives that may affect the relationships of these factors in the future.

Over the last several decades, the number of overweight or obese children has reached alarming levels worldwide. In 2013, $23.8 \%$ of boys and $22.6 \%$ of girls in developed countries were overweight or obese. However, recently, many advanced countries have begun undertaking measures to prevent child and adolescent obesity (Table 3). Although there are differences in policies and strategies to reduce childhood obesity among developed countries such as WHO [27], EU [28], UK [29-31], Australia [25], and the USA [32-34], there are some commonalities comprehensive approaches to obesity prevention, establishment of multi-part participation and partnerships as well as policy, legal, and institutional approaches affecting diet and physical activity, selection of essential business areas for obesity prevention, strategies to increase the supply and demand of healthy foods, strategies to promote physical activity of the population, and re-recognition of the role of healthcare institutions in monitoring, evaluating, and researching obesity. In particular, Trim and Fit (TAF) was a weight loss program that targeted childhood obesity in Singapore schools between 1992 and 2007, conducted by the Ministry of Education [35]. Schoolchildren under the TAF program were educated on nutrition, calorie control, and participated in physical activities, and the program was successful in reducing the obesity rate from $14 \%$ to $9.8 \%$ by 2002 . In Korea, the "Safety Assurance on Food and Eating/Nutrition Environment (SAFENET) for Children (09-11)"program supported the estabilishment of "the Center for Childcare Foodservice Management (CCFSM)" and 220 centers were nationally operating by 2019 [36].

As another important issue, the significant impact of the human microbiome on human diseases and health conditions was identified during the second half of the 2000s. The gastrointestinal tract microbiome has been well investigated, and an association with illness has been demonstrated in many diseases (Table 4). In 2016, the US National Microbiome Initiative (NMI) plan was announced with an investment of \$121 million (about \$144 billion) over 2 years for studying the interactions among crops, livestock, and microbes, human diseases and microbes, and astronauts and microorganisms [37]. In the EU, the Metagenomics of the Human Intestinal Track (MetaHIT) project played an important role in elucidating the causal relationship between microbes and human functions. As 
Table 3. International policies or programs for the prevention of children obesity

\begin{tabular}{|c|c|c|}
\hline Country \& Int Organ & Policy or Programme & Organizer \& Sponsor \\
\hline WHO & $\begin{array}{l}\text { European charter on counteracting obesity } \\
\text { Health promoting school }\end{array}$ & WHO European Ministerial Conference: \\
\hline EU & $\begin{array}{l}\text { EU Action Plan on Childhood Obesity 2014-2020 } \\
\text { EPODE European Network; EPODE ('Ensemble Prévenons l'Obésité Des Enfants') means } \\
\text { "Together Let's Prevent Childhood Obesity") }\end{array}$ & EC Member State \\
\hline USA & $\begin{array}{l}\text { "Let's Move" } \\
\text { NPAO (Nutrition and Physical Activity Program to Prevent Obesity) } \\
\text { CATCH (Coordinated Approach to Child Health) }\end{array}$ & CDC \& 28 State Government \\
\hline UK & $\begin{array}{l}\text { Preventing Childhood Obesity (2005) } \\
\text { Healthy Weight, Healthy Lives; A Cross-Government Strategy for England (2008-) }\end{array}$ & $\begin{array}{l}\text { Cross-Government Obesity Unit, } \\
\text { Department of Health and Department } \\
\text { of Children, Schools and Families }\end{array}$ \\
\hline Australia & Action Agenda, Healthy Weight 2008: Australia's Future. & $\begin{array}{l}\text { The department of Health \& National } \\
\text { Obesity Taskforce Secretariat }\end{array}$ \\
\hline Singapore & Trim and Fit (TAF), Holistic Health Framework (HHF) & Ministry of Education \\
\hline Korea & $\begin{array}{l}\text { Safety Assurance on Food and Eating/Nutrition EnvironmenT (SAFENET) for Children (09-11) } \\
\text { Safety Control of Children's Dietary Life (Active } 215 \text { units until 2018): The } 220 \text { centers for } \\
\text { child-care foodservice management (CCFSM) were nationally set-up. }\end{array}$ & Ministry of Food and Drug Safety \\
\hline
\end{tabular}

Table 4. Major microbiome projects in many countries

\begin{tabular}{|c|c|c|c|}
\hline Country & Project & Duration & Objective \\
\hline International- & International Human Microbiome Consortium (IHMC) & $10-$ & $\begin{array}{l}\text { Set principles \& policies to study microbiome. Mediate projects to } \\
\text { generate a comprehensive data resource. }\end{array}$ \\
\hline \multirow[t]{4}{*}{ EU } & Metagenomics of the Human Intestinal Tract (MetaHIT) & $08-11$ & $\begin{array}{l}\text { Construct large catalog of intestinal microbiome and genes of IBD } \\
\text { and obesity. }\end{array}$ \\
\hline & International Human Microbiome Standards (IHMS) & $11-15$ & Establish a standard protocol for human microbiome studies \\
\hline & MicroObes (France) & $08-10$ & Research on obesity and human intestinal microbiome. \\
\hline & MetaGenoPolis (France MGP) & $12-19$ & $\begin{array}{l}\text { The correlation of non-infectious diseases \& international } \\
\text { microbiome. }\end{array}$ \\
\hline \multirow[t]{6}{*}{ USA } & $\mathrm{NIH}$ Human Microbiome Project (HMP) & 08-15 & $\begin{array}{l}\text { Generate human microbiome. Diagnosis and treatment through a } \\
\text { correlation between diseases and microbiome. }\end{array}$ \\
\hline & Home Microbiome Project. & $12-$ & Analyze bacterial community in living space \\
\hline & Data Analysis and Coordination Center (DACC) & 08-13 & Assist in standard of data pipeline. \\
\hline & Hospital Microbiome Project & $12-14$ & $\begin{array}{l}\text { Analyze bacterial community in hospital, \& find correlation } \\
\text { between the bacteria \& patient. }\end{array}$ \\
\hline & Microbiome Quality Control Project (MBQC) & $13-$ & Establish analytic pipeline of human fecal microbiome. \\
\hline & American Gut Project & $13-$ & Study of bacterial diversity of the public \& construct data resource. \\
\hline Canada & Canadian Microbiome Initiative (CMI) & 09- & $\begin{array}{l}\text { Support seven research teams to conduct a prospective study of } \\
\text { diseases by modeling and mapping microbial diversity }\end{array}$ \\
\hline \multirow[t]{3}{*}{ Korea } & Korean Microbiome Initiative & $07-$ & Develop drugs using microbiome \\
\hline & Korean microbiome diversity using Korean Twin Cohort project & $10-15$ & $\begin{array}{l}\text { Human diseases related microbiome using twin cohort and } \\
\text { characterize Korean specific microbiome }\end{array}$ \\
\hline & Strategic initiative for microbiomes in agriculture and food & $14-21$ & Develop and market products using intestinal microorganisms \\
\hline Australia & The Australian Jumpstart Human Microbiome Project & 09 & $\begin{array}{l}\text { Analyze metagenome of intestinal microbes and Australian specific } \\
\text { microbiome. }\end{array}$ \\
\hline Japan & Japanese Consortium for Human Microbiome (JCHM) & $14-$ & $\begin{array}{l}\text { Study of Japanese specific intestinal microbiome and disease } \\
\text { biomarker. }\end{array}$ \\
\hline
\end{tabular}

memebrs of the same race are known to have very different distributions of intestinal microbes, it has been determined that intestinal microbes differ based on lifestyle, especially diet [38]. Although many human microbiome studies have been reported, a precise characterization of human-associated microorganisms is required. Fortunately, standardization or quality control of the comprehensive data generated in many large projects is underway through the International Human Microbiome Consortium [37-41].

Although the Korean National Health and Nutrition Survey provides basic data for the prevention of obesity by surveying people's consumption of food and nutrients, less is known about the food environment, including the purchasing patterns of agricultural products and the effects of eating out and the food industry. Thus, although various ministries are carrying out obesity research projects, they also need to analyze the unique obesity issue in Korea as well as select short- and long-term roadmaps that account for social issues in order to engage in multi-ministerial cooperation to bring about successful results. 
Research on obesity and obesogenic environments in Korea

Seoul Metropolitan Government Development Institute Supportive Metabolic Syndrome Treatment (composition of obesity cohort; 2010-2015)

This project supported the establishment of an industryacademic cluster for the purpose of improving the health of the Seoul population and fostering Asian and Pacific medical hub cities. The project focused on the treatment of metabolic syndrome, with focuses on dyslipidemia, obesity, diabetes, and high blood pressure. A 5-year F/W cohort of metabolic syndrome was established based on a network of experts linked to each field for the development of new customized treatments, and emphasis was placed on gene diagnosis methods for metabolic syndrome and the development of individual customized treatment methods. Published findings from this project may help improve knowledge of metabolic syndrome as well as the value of the medical industry [42-47].

New Biomaterials Center for Anti-Obesity (NBiCA) supported by the Ministry of Food, Agriculture, Forestry, and Fisheries (2011-2014)

This business group established a new material screening method suitable for systematic obesity to facilitate standardization of anti-obesity materials presented in Korea and abroad. A stepwise standardization method for verifying physiological activity included a new screening method and standardization of materials, construction of pre-clinical/clinical trial modeling, stability verification, human application tests for individual recognition, and anti-inflammatory obesity biomarker verification technology. Once the efficiency of an anti-obesity material (product) to prevent and treat obesity can be verified, it will contribute to the revitalization of the obesity market by transferring the technology to industry [48-52].

Obesity Gene Customized Food Development Project supported by the Ministry of Food, Agriculture, Forestry, and Fisheries (2012-2015)

This project proposed personalized meals based on obesity phenotype (basic metabolism etc.) by identifying food patterns associated with obesity-related genotypes using gene discovery techniques such as GWAS related to the occurrence of obesityrelated diseases such as hypertension and arteriosclerosis in Korea. In particular, the obesity metabolic pathway was traced around the metabolism associated with the obesity gene, and mGWAS related to obesity was completed [53-55].

Child and Adolescent Obesity Prevention Management Project supported by the Ministry of Science, ICT, and Future Planning (2013 in progress)

In order to establish an efficient childhood obesity management system combined with IT and BT, six field research systems (metabolic biometric development/diagnosis, content design, custom content development, service platform development, demonstration business, and service) were developed. As an approach, the government attempted to set services involving students/parent/teacher participants, establish a school house continuous management system, improve awareness of correct living habits centered on education, provide a basis through medical/nutritional/sports/educational experts, and build up school-centered demonstration services. The purpose of this project was to develop or optimize an integrated platform for preventing and managing childhood and adolescent obesity. However, difficulties in self-care and ongoing management, inability to identify the transition to adult obesity, lack of correct obesity information, lack of a systematic health education base for child obesity management, need for application services at a child's eye level, and user convenience due to developeroriented service development are problems that remain to be addressed [56-58].

Bio-Synergy Research Center (BSRC) supported by the Ministry of Science and ICT (2013-in progress)

The Bio-Synergy Research Center focused on IT and BT to combat obesity and aging in the personalized medicine era, and tried to contribute to national health policy. In particular, multicomponent multi-target technology and multi-omics-based systems biology were established for materials, markers, targets, and human testing on an integrated chemical biological basis in order to develop a low-cost, high-efficiency, bio-specialized support system. In addition, the establishment of a virtual human system to develop a technology to interpret and predict the efficacies of anti-obesity materials will provide a good model for future anti-obesity research [59-61].

Cross-research of the Human Microbiome Initiative supported by governmental departments (2007-in progress)

Starting with the Human Microbiome Initiative in 2007, large-scale national projects have been emphasized, with the Korea Drug Development Fund (2007-in progress) focusing on the development of treatment drugs using microbiome targets for a variety of diseases, and involving global pharmaceutical companies such as J\&, BMS, Pfizer, and Abbvie [62]. As a cross-ministry research project, the Korea Post-Genome Project, a strategic initiative focused on the microbiome in agriculture and food (2014-2021), supported by the Ministry of Agriculture, Food, and Rural Affairs seeks to find ways to develop and market products by using intestinal microorganisms through tracking changes in intestinal microorganisms according to diet. Other studies related to the occurrence of diseases and metabolites produced by intestinal microbes are being conducted in small-scale, state-funded studies and actively participate in the data collection of international organizations [37, 63, 64].

\section{Summary}

Anti-obesity projects conducted since the year 2010 have mostly been properly conducted by the appropriate departments and agencies relevant to each category. For example, the composition of the cohort to identify causal relationships between obesity and environmental factors has been supported by the Seoul Metropolitan Government. The Ministry of Food, Agriculture, Forestry, and Fisheries supports the development of anti-obesity materials and related foods. The establishment of anti-obesity services for childhood and adolescents is supported by the Ministry of Science. Lastly, multi-technology convergent, personalized treatment systems such as IT, BT, and 
$\mathrm{CT}$ for anti-obesity treatment are supported by the Ministry of Science and ICT. It is encouraging that the Rural Development Administration, Ministry of Food and Drug Safety, Ministry of Oceans and Fisheries, and Ministry of Culture, Sports, and Tourism are supporting sustainable research projects to prevent obesity. However, it is unfortunate that a collective integrated multidisciplinary project has not been organized to develop into an interconnected business by utilizing the characteristics of each supporting organization during the planning phase of various anti-obesity projects. This approach has the advantages of not only saving funds but also preventing confusing feedback, thereby making it easier to plan new avenues for research in the future.

\section{Future anti-obesity nutrition research modeling and policy proposals}

Population-based policies (socioeconomic cost reduction)

Several states in the US are implementing systems to refund medical expenses if obese patients meet their targets, and the Let's Move campaign encourages students to perform physical activities for more than 60 minutes a day. In Mexico, the government provides financial incentives for those who manage their own weight, such as giving them a ticket for 10 squats on a measuring device installed at a subway station [65-66]. Germany encourages active physical activity by giving badges to teenagers who pass physical activity tests through the Sport Badge for Youth campaign. In some countries, obesity taxes are even imposed on processed or junk food with high salt or sugar content. In 2011, Hungary passed a bill called the 'Act CIII of 2011 on the Public Health Product Tax (PHPT)', which required mandatory taxes on beverages with high levels of sugar, salt, and caffeine [67]. As a result, the vendor replaced the ingredients of the product, and consumption decreased by about 30\% compared to the previous year. In England, an imposition of sugar tax per $100 \mathrm{~mL}$ soda including $>5 \mathrm{~g}$ sugar was started in 2018. In France, soda consumption dropped $6.7 \%$ in just 2 years after the implementation of the soda tax $(€ 11$ per $1.5 \mathrm{~L}$ of sweetened beverage), whereas soda consumption dropped $21 \%$ in Berkeley, California after the imposition of a one cent soda tax per ounce [68]. In future, sugar taxes ahve been considered in Chile, India, Indonesia, Mexico, the Philippines, and so on.

\section{Environmental-based policies}

Environmental-based policies refer to policies that attempt to counteract environments that make schools, universities, workplaces, communities, health facilities, and religious facilities vulnerable to obesity. Typically, the school meal program is a long-standing anti-obesity strategy that has helped improve eating habits of school-age children by providing them with a balanced diet including fruits and vegetables that are readily available in the region. For example, the National School Lunch (Breakfast) Program in the US prohibits the sale and provision of food that is not nutritious and provides free fresh fruit and vegetables to students. Britain's Five-A-Day campaign ('Five-aday, a price to pay: an evaluation of the UK program impact accounting for market forces) that promotes consumption of five servings of fruits and vegetables per day was found to be effective in a 4-year (2002-2006) policy analysis [69]. Singapore's The Healthier Choice Symbol Program involves labeling low-fat, low-saturated, low-salt, and low-sugar products so that consumers can make healthier choices when purchasing food [70]. As a result, we identified the effects of improving the percentage of healthy food choices, increasing the proportion of people who eat adequate amounts of vegetables and fruits, and decreasing the percentage of people who eat high amounts of salt (salt, sauce, etc.).

\section{Personalized policies by lifecycle}

In 2003, the US government completed the 'Human Genome Project' an international scientific project that identified the sequence of nucleotide base pairs (more than three billion) that make up the entirety of human DNA. The revolutionary project provided scientific data for bioinformatics to identify the genetic source of non-communicable diseases. According to projects on sodium sensitive genes, 11 genes found in obese children through GWAS were shown to be strongly connected with a high risk of obesity in girls in conjunction with increased sodium intake over a 3-year period [53,71]. The authors suggested that girls with the hetero/mutant allele of the CYP11ß2 and NEDD4L genes should reduce their daily sodium intake to prevent obesity. The obesogenic variables affected by the alleles of genes were different among overweight/obese subjects in response to functional food [72] Kochujang, a Korean fermented soybean-based red pepper paste, has been reported to have a fat-reducing effect. However, the beneficial effects of Kochujang on the lowering of TG and TG/HDL were weakened in subjects with the PPARy 2 mutant $T$ allele, accompanied by an increased subcutaneous fat area [73].

In addition to genes, we must also consider the microbiome, which is a key component of precision medicine. Understanding how host-microbe associations are maintained in populations will help reveal individualized host-microbiome encoded disease phenotypes that can be integrated with multi-omics data sets to enhance precision medicine [74]. If metabolism changes and persists depending on human gene expression or intestinal microbes, the causal relationship leading to the disease can be understood using bioinformatics.

Moreover, since there are different morphological causes of obesity occurring over the whole lifecycle, the policy of preventing obesity according to lifecycle stage should be established based on intervention studies that incorporate lifecycle. In particular, efforts to increase effectiveness through comprehensive approaches to various determinants are needed to combat childhood obesity, which is a major cause of adult obesity. The OECD has warned that, even in countries like Korea where the current obesity rate is low, obesity will continue to escalate within the next 10 years without proper intervention.

Designing research modeling to understand complex factors The International Obesity Task Force (IOTF) presented the Causal Web, which explains the critical factors and pathways of obesity, shows that obesity results from complex factors in the social, economic, cultural, physical, or genetic environment and cannot be addressed with simple solutions [75]. The OECD's 2008 report entitled. The Prevention of Lifestyle-Related Chronic 


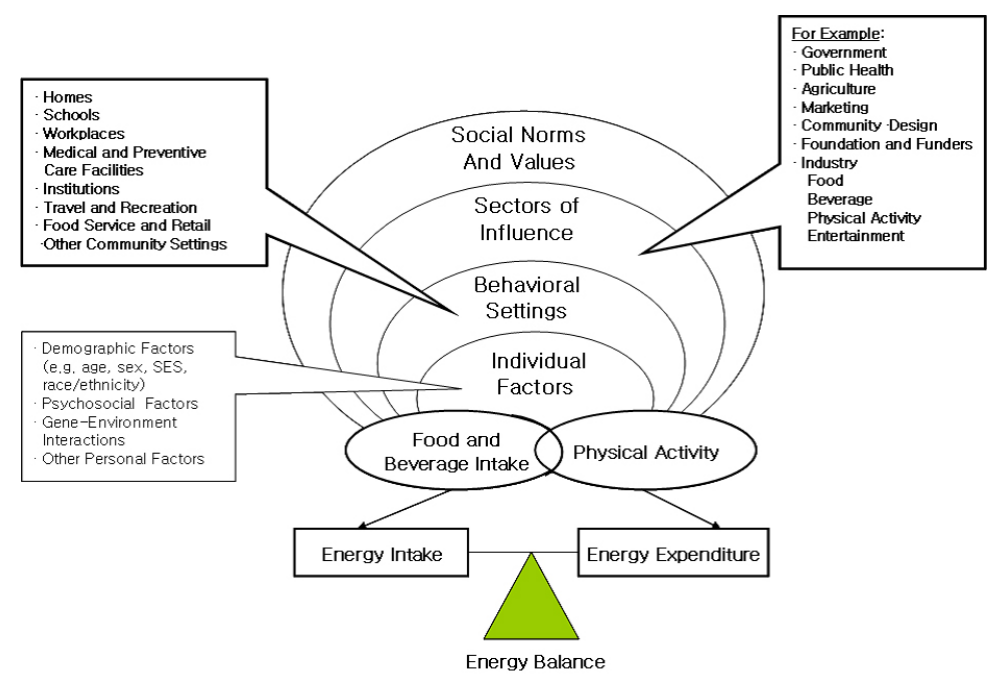

Fig. 5. CDC Division of Nutrition, Physical Activity and Obesity, State Nutrition, Physical Activity and Obesity (NPAO) Program, Technical Assistance Manual, January 2008.) https://mww.cdc.gov/obesity/downloads/dnpao_evidence_sources_factsheet.pdf (ref;76)

Conditions, cited six factors affecting population lifestyle: individual behavior factors, education, socioeconomic factors, supplier's side factors, environmental factors, and health care system factors. A representative approach model for the anti-obesity industry that reflects this is the NPAO in the US and the UK's Obesity System Map (Fig. 5) [76]. Thus, crosscollaboration is imperative between health and medical institutions as well as related agencies. Instead of policy and action plans, it is necessary to establish a road map for managing the progress and performance of projects inorder to provide objective results in a fixed period of time, with a focus on monitoring and impact assessment.

\section{ACKNOWLEDGEMENTS}

Contents presented at the International Symposium for Prevention Policy of Obesity at $21^{\text {th }}$ of June, 2018, jointly organized by the Korea Agricultural Promotion Agency, the Korean Society of Nutrition, and the Korean Regional Society, and Nutrition Society, were invited for submission to the NRP Journal. Some of the contents were excluded and edited to fit the format of the review.

\section{CONFLICT OF INTEREST}

The author declares no potential conflicts of interests.

\section{ORICD}

Myoungsook Lee: https://orcid.org/0000-0003-1344-6979

\section{REFERENCES}

1. Organization for Economic Co-operaion and Development (OECD). OECD obesity update 2017. Paris:OECD 2017 [Cited 2017 May 18]. Available from: http://www.oecd.org/health/obesity-update.htm.

2. Ministry of Health and Welfare, Korea Centers for Disease Control and Prevention. 2013-2014 National Health Nutrition Examination Survey Report [Internet]. Cheongju: Korea Centers for Disease Control and Prevention; 2014 [cited 2015 Dec 1]. Available from: https://knhanes.cdc.go.kr/knhanes/index.do.

3. Seo MH, Kim YH, Han K, Jung JH, Park YG, Lee SS, Kwon HS, Lee WY, Yoo SJ. Prevalence of obesity and incidence of obesity-related comorbidities in Koreans based on National Health Insurance Service health checkup data 2006-2015, J Obs Metab Syndr 2018;27:46-52.

4. Yoon YS, Oh SW. Recent shift of body mass index distribution in Korea: a population-based Korea national health insurance database, 2002-2013. J Korean Med Sci 2017;32:434-8.

5. Ministry of Education (KR), 2015 Sample statistics reports for student's health examination in elementary, middle \& high school, 2015. [Internet]. Sejong: Ministry of Education; 2015 [Cited 2015 December]. Available from: http://www.gbe.kr/cmmn/download. do?idx=1408721.

6. OECD, Health at a Glance 2017: OECD Indicators. Paris: OECD Publishing.

7. Kim MK, Lee, Lee WY, Kang JH, Kang JH, Kim BT, Kim SM, Kim $E M$, Suh SH, Shin HJ, Lee KR, Lee KY, Lee SY, Lee SY, Lee SK, Lee CB, Chung S, Jeong IK, Hur KY, Kim SS, Woo JT; Committee of Clinical Practice Guidelines; Korean Society for the Study of Obesity. 2014 clinical pratice guidelines for overweight and obesity in Korea. Endocrinol Metab (Seoul) 2014;29:405-9.

8. Kim YE, Lee YR, Yoon SJ, Kim YA, Oh IH. Years of life lost due to premature death in people with disabilities in Korea: the Korean national burden of disease study framework. J Korean Med Sci 2019;34:e22.

9. Cleveland Clinic (US). Obesity is top cause of preventable life-years lost, study shows [Internet]. Rockville (MD): Science Daily; 2017 [Cited 2017 April 22]. Available from: https://www.sciencedaily.com/ releases/2017/04/170422101614.htme

10. Lee JE, Nam CM, Lee SG, Park S, Kim TH, Park CH. The economic burden of cancer attributable to obesity in Korea: a populationbased cohort study. Eur J Cancer Care (Engl) 2019;28:e13084.

11. Lee SM, Paik JW, Kim SH, Kang HL. A Study on Construction of 
Obesity Management to Improve the Disability Adjusted Life Expectancy. Wonju: National Health Insurance Service; 2017.

12. National Institute of Food and Drug Safety Evaluation. Amendment for Product-Specific Health Functional Food Ingredients. Cheongju: National Institute of Food and Drug Safety Evaluation; 2018.

13. KIPRIS. Title [Internet]. Daejeon: KIPRIS; 2019 [Cited 2019 Sep 3]. Available from: http://kportal.kipris.or.kr/kportal/search/total_search.do.

14. Ministry of Food and Drug Safety (KR). 2016 Ministry of food and drug safety white paper [Internet]. Cheongju: Ministry of Food and Drug Safety; 2016 [Cited 2016 July]. Available from: http://www. kobia.kr/skin/bbs/downloads_e2/download.php?tbl=policy_report\& no $=405$.

15. James WP, Caterson ID, Coutinho W, Finer N, Van Gaal LF, Maggioni AP, Torp-Pedersen C, Sharma AM, Shepherd GM, Rode RA, Renz $\mathrm{CL}$; SCOUT Investigators. Effect of sibutramine on cardiovascular outcomes in overweight and obese subjects. N Engl J Med 2010:363:905-17.

16. Korea Health Promotion Institute. Health promotion research project of Ministry of Health \& Welfare, evaluation framework for obesity prevention policy [Internet]. Seoul: Korea Health Promotion Institute; 2016 [Cited 2019 Sep 3]. Available from: http://www. khealth.or.kr.

17. Korea Institute for Health and Social Affairs. A study on the development of policy and strategies for national overweight and obesity prevention programs in children and adolescents [Internet]. Sejong: Korea Institute for Health and Social Affairs; 2009 [Cited 2009 January]. Available from: https://www.kihasa.re.kr/common/ filedown.do?seq=17203.

18. Seo YJ, Jeon MS. Effects of an education program on sanitation status at centers for children's food service management: focusing on Jung-gu and Dong-gu regions of Daejeon Metropolitan City. Korean J Community Nutr 2015;20:447-59.

19. Ju SY, Hong WS. Assessment of the effectiveness and perception of education by center for child-care foodservice management: focus on parents of child-care and kindergarten in Seoul. Korean J Food Cookery Sci 2018;34:404-12.

20. Trust of America's Health. The state of obesity 2018: better policies for a healthier America [Internet]. Washington, D.C.: Trust of America's Health; 2018 [Cited 2018 September]. Available from: https://www.tfah.org/report-details/the-state-of-obesity-2018.

21. Interagency Committee on Human Nutrition Research (US). National nutrition research roadmap 2016-2021: advancing nutrition research to improve and sustain health [Internet]. Washington, D.C.: Interagency Committee on Human Nutrition Research; 2016 [Cited 2016 November 2]. Available from: https://www.nal.usda.gov/sites/ default/files/fnic_uploads/2016-03-30-\%20ICHNR\%20NNRR\%20\%28 2\%29.pdf.

22. Interagency Committee on Human Nutrition Research (US). National nutrition research roadmap 2016-2021: advancing nutrition research to improve and sustain health executive summary [Internet]. Washington, D.C.: Interagency Committee on Human Nutrition Research; 2016 [cited 2016 November 2]. Available from: https:// www.nal.usda.gov/fnic/interagency-committee-human-nutrition-res earch.

23. United States Department of Agriculture. National program 107 human nutrition [Internet]. Washington, D.C.: United States Department of Agriculture; 2015 [cited 2015 December 25]. Available from: http://fliphtml5.com/kcka/ujth/basic.

24. National Agricultural Research Organization (JP). The Food Research Institute, NARO (NFRI) conducts innovative R\&D to ensure a safe and healthy dietary life and resolve food issues in Japan [Internet]. Tsukuba: National Agricultural Research Organization; 2017 [cited 2017 March]. Available from: http://www.naro.affrc.go.jp/publicity _report/publication/files/nfri_pamphlet_en.pdf.

25. The Australian Health Ministers Advisory Council. Healthy weight 2008 - Australia's future - the national action agenda for children and young people and their families [Internet]. Canberra: The Australian Health Ministers Advisory Council; 2011 [cited 2011 July 4]. Available from: http://www.health.gov.au/internet/publications/ publishing.nsf/Content/healthy-weight-2008.

26. Government Office for Science (GB). Research and analysis reducing obesity: obesity system map [Internet]. London: Government Office for Science; 2007 [cited 2007 October 2007]. Available from: https://www.gov.uk/government/publications/reducing-obesity-ob esity-system-map.

27. World Health Organization. Health promoting schools [Internet]. Geneva: World Health Organization; 2018 [Cited 2019 Sep 3]. Available from: https://www.who.int/health-promoting-schools/en/.

28. European Commission. EU action plan on childhood obesity 2014-2020 [Internet]. Brussels: European Union; 2014 [cited 2014 July 28]. Available from: https://ec.europa.eu/health/sites/health/ files/nutrition_physical_activity/docs/childhoodobesity_actionplan_ 2014_2020_en.pdf.

29. Royal Society for Public Health (GB). The child's obesity strategy: how our young people would solve the childhood obesity crisis [Internet]. London: Royal Society for Public Health; 2016 [cited 2016 June 23]. Available from: https://www.rsph.org.uk/uploads/assets/ uploaded/403f6527-dd7a-4b7e-8ad62dab7bef33fd.pdf.

30. National Obesity Forum (GB). Childhood obesity: the scale of the problem [Internet]. Nottingham: National Obesity Forum; 2015 [Cited 2019 Sep 3]. Available from: http://www.nationalobesity forum.org.uk/images/stories/PDF_training_resource/in-depth-child hood-obesity.pdf.

31. Cross-Government Obesity Unit, Department of Health and Department of Children, Schools and Families (GB). Healthy weight, healthy lives: a cross-government strategy for England [Internet]. London: Cross-Government Obesity Unit; 2008 [cited 2008 January 23]. Available from: http://webarchive.nationalarchives.gov.uk/2013 0401151715/http://www.education.gov.uk/publications/eOrdering Download/DH-9087.pdf.

32. Hamre R, Kuester S, Renaud J, Williams-Piehota P, Franco E, Roussel A, Hersey J. Improving nutrition, physical activity, and obesity prevention [Internet]. Atlanta (GA), Research Triangle Park (NC): Centers for Disease Control, RTI International; 2006 [cited 2006 July]. Available from: https://www.cdc.gov/obesity/downloads/NPAO_Performance _Report_2005.pdf.

33. The University of Texas Health Science Center at Houston. CATCH - coordinated approach to child health: curriculum \& training [Internet]. Houston (TX): The University of Texas Health Science Center at Houston; 2018 [cited 2018 March 8]. Available from: https://www.cdc.gov/prc/resources/pdf/tools/CATCH_508tagged.pdf.

34. Hoelscher DM, Springer AE, Ranjit N, Perry CL, Evans $A E$, Stigler $\mathrm{M}$, Kelder SH. Reductions in child obesity among disadvantaged school children with community involvement: the Travis County CATCH Trial. Obesity (Silver Spring) 2010;18 Suppl 1:S36-44. 
35. Ministry of Education Singapore. Educating for health conference [Internet]. Singapore: Ministry of Education Singapore; 2007 [cited 2007 November 12]. Available from: http://www.nas.gov.sg/ archivesonline/data/pdfdoc/20071112983.pdf.

36. Ministry of Food and Drug Safety (KR). Safety assurance on food and eating/nutrition environment (SAFENET) for children [Internet]. Cheongju: Ministry of Food and Drug Safety; 2011 [cited 2011 November 30]. Available from: http://www.ndsl.kr/ndsl/search/detail/ report/reportSearchResultDetail.do?cn=TRKO201600010653.

37. MetaHit. MetaHit website [Internet]. [place unknown]: INRA - MICA Division; 2008 [cited 2011 June 1]. Available from: http://www. metahit.eu/.

38. NIH HMP Working Group, Peterson J, Garges S, Giovanni M, Mclnnes P, Wang L, Schloss JA, Bonazzi V, McEwen JE, Wetterstrand KA, Deal C, Baker CC, Di Francesco V, Howcroft TK, Karp RW, Lunsford RD, Wellington CR, Belachew T, Wright M, Giblin C, David H, Mills M, Salomon R, Mullins C, Akolkar B, Begg L, Davis C, Grandison L, Humble M, Khalsa J, Little AR, Peavy H, Pontzer C, Portnoy M, Sayre MH, Starke-Reed P, Zakhari S, Read J, Watson B, Guyer M. The NIH human microbiome project. Genome Res 2009;19:2317-23.

39. Choi S, Cho SH, Yi H. Human microbiome studies in Korea. Allergy Asthma Respir Dis 2016;4:311-20.

40. Kyrpides NC, Eloe-Fadrosh EA, Ivanova NN. Microbiome data science: understanding our microbial plane. Trends Microbiol 2016;24:425-7.

41. Gombojav B, Song YM, Lee K, Yang S, Kho M, Hwang YC, Ko G, Sung J. The healthy twin study, Korea updates: resources for omics and genome epidemiology studies. Twin Res Hum Genet 2013;16: 241-5.

42. Lee M, Jang Y, Kim K, Cho H, Jee SH, Park Y, Kim MK. Relationship between $\mathrm{HDL}_{3}$ subclasses and waist circumferences on the prevalence of metabolic syndrome: KMSRI-Seoul study. Atherosclerosis 2010; 213:288-93.

43. Hong $S$, Song $Y$, Lee $K H$, Lee $H S$, Lee $M$, Jee $S H$, Joung $H$. A fruit and dairy dietary pattern is associated with a reduced risk of metabolic syndrome. Metabolism 2012;61:883-90.

44. Kim $Y$, Lee $M$, Lim $Y$, Jang $Y$, Park HK, Lee $Y$. The gene-diet interaction, LPL Pvull and Hindlll and carbohydrate, on the criteria of metabolic syndrome: KMSRI-Seoul study. Nutrition 2013;29: 1115-21.

45. Shin E, Park NY, Jang Y, Oh H, Jeong J, Lim Y, Lee M. The association of lipoprotein lipase Pvull polymorphism and niacin intake in the prevalence of metabolic syndrome: a KMSRI-Seoul study. Genes Nutr 2012;7:331-41.

46. Jung $\mathrm{KJ}$, Jee $\mathrm{YH}$, Jee $\mathrm{SH}$. Metabolic risk score and vascular mortality among Korean adults. Asia Pac J Public Health 2017;29:122-31.

47. Oh HY, Kim MK, Lee M, Kim YO. Macronutrient composition and sodium intake of diet are associated with risk of metabolic syndrome and hypertension in Korean women. PLoS One 2013;8:e78088.

48. Lee MR, Lim CJ, Lee YH, Park JG, Sonn SK, Lee MN, Jung IH, Jeong SJ, Jeon S, Lee M, Oh KS, Yang Y, Kim JB, Choi HS, Jeong W, Jeong TS, Yoon WK, Kim HC, Choi JH, Oh GT. The adipokine Retnla modulates cholesterol homeostasis in hyperlipidemic mice. Nat Commun 2014;5:4410.

49. Choi M, Park H, Cho S, Lee M. Vitamin D3 supplementation modulates inflammatory responses from the muscle damage induced by high-intensity exercise in SD rats. Cytokine 2013;63: 27-35.
50. Lim HH, Yang SJ, Kim Y, Lee M, Lim Y. Combined treatment of mulberry leaf and fruit extract ameliorates obesity-related inflammation and oxidative stress in high fat diet-induced obese mice. J Med Food 2013;16:673-80.

51. Kim SY, Wi HR, Choi S, Ha TJ, Lee BW, Lee M. Inhibitory effect of anthocyanin-rich black soybean testa (Glycine max (L.) Merr.) on the inflammation-induced adipogenesis in a DIO mouse model. J Funct Foods 2015;14:623-33.

52. Eo H, Jeon YJ, Lee M, Lim Y. Brown Alga Ecklonia cava polyphenol extract ameliorates hepatic lipogenesis, oxidative stress, and inflammation by activation of AMPK and SIRT1 in high-fat diet-induced obese mice. J Agric Food Chem 2015;63:349-59.

53. Lee $M, K w o n$ DY, Park J. The impacts of the interaction of genetic variation, CYP11B2 and NEDD4L, with sodium intake on pediatric obesity with gender difference: a 3-year panel study. Int J Obes 2017; 41:542-50

54. Lee M, Kwon DY, Kim MS, Choi CR, Park MY, Kim AJ. Genome-wide association study for the interaction between BMR and BMl in obese Korean women including overweight. Nutr Res Pract 2016;10:115-24.

55. Choi JR, Kwon IS, Kwon DY, Kim MS, Lee M. TT mutant homozygote of Kruppel-like factor 5 is a key factor for increasing basal metabolic rate and resting metabolic rate in Korean elementary school children. Genomics Inform 2013;11:263-71.

56. Cho K, Moon JS, Kang JH, Jang HB, Lee HJ, Park SI, Yu KS, Cho JY. Combined untargeted and targeted metabolomic profiling reveals urinary biomarkers for discriminating obese from normalweight adolescents. Pediatr Obes 2017;12:93-101.

57. Lee JE, Lee $D E$, Kim K, Shim JE, Sung E, Kang JH, Hwang JY. Development of tailored nutrition information messages based on the transtheoretical model for smartphone application of an obesity prevention and management program for elementary-school students. Nutr Res Pract 2017;11:247-56.

58. Kim H, Kang JH, Park HA, Cho SH, Jeon SH, Jung JH, Sung $S$. Development of a smartphone application prototype for child obesity prevention: rationale and study design of acceptability and feasibility tests. Korean J Health Promot 2015;15:194-201.

59. Song $M$, Kang K, An JY. Investigating drug-disease interactions in drug-symptom-disease triples via citation relations. J Assoc Inf Sci Technol 2018;69:1355-68.

60. Gu MY, Chun YS, Yong RS, Yang HO. Licoflavonol reduces $A B$ secretion by increasing BACE1 phosphorylation to facilitate BACE1 degradation. Mol Nutr Food Res 2019;63:e1800474.

61. Kim YJ, Kim S, Jung Y, Jung E, Kwon HJ, Kim J. Eupatilin rescues ciliary transition zone defects to ameliorate ciliopathy-related phenotypes. J Clin Invest 2018;128:3642-8.

62. Hong CP, Park A, Yang BG, Yun CH, Kwak MJ, Lee GW, Kim JH, Jang MS, Lee EJ, Jeun EJ, You G, Kim KS, Choi Y, Park JH, Hwang D, Im SH, Kim JF, Kim YK, Seoh JY, Surh CD, Kim YM, Jang MH. Gut-specific delivery of t-helper 17 cells reduces obesity and insulin resistance in mice. Gastroenterology 2017;152:1998-2010.

63. Nam YD, Jung MJ, Roh SW, Kim MS, Bae JW. Comparative analysis of Korean human gut microbiota by barcoded pyrosequencing. PLoS One 2011;6:e22109.

64. Strategic Initiative for Microbiomes in Agriculture and Food (KR). Report for the research and the trend of microbiome [Internet]. Seoul: Strategic Initiative for Microbiomes in Agriculture and Food; 2015 [cited 2015 August 10]. Available from: http://moog2015. cafe24.com/bizdemo21250/img/report001.pdf. 
65. OECD. OECD obesity update 2014 [Internet]. Paris: OECD; 2014 [cited 2014 June]. Available from: http://www.oecd.org/health/ Obesity-Update-2014.pdf.

66. Mexico New Daily. Subway ticket worth 10 squats in DF [Internet]. Oaxaca: Mexico New Daily; 2015 [cited 2015 January 27]. Available from: https://mexiconewsdaily.com/news/subway-ticket-worth-10squats-df/.

67. WHO Regional Office for Europe. Assessment of the impact of a public health product tax [Internet]. Copenhagen: WHO Regional Office for Europe; 2015 [cited 2015 November 11]. Available from: http://www.euro.who.int/_data/assets/pdf_file/0008/332882/assess ment-impact-PH-tax-report.pdf.

68. Kim YM. Current status of obesity and countermeasure [Internet]. Seoul: Korea Insurance Research Institute; 2017 [cited 2017 October 16]. Available from: http://www.kiri.or.kr/pdf/\%EC\%A0\%84\%EB\%AC \%B8\%EC\%9E\%90\%EB\%A3\%8C/KIRI_20171012_174540.pdf.

69. World Health Organization. $5 \mathrm{~A}$ day for better health program USA [Internet]. Geneva: World Health Organization; 2003 [cited 2003 August 26]. Available from: https://www.who.int/dietphysicalacti vity/media/en/gs_fv_ppt_lorelei.pdf?ua=1.

70. Tan A, Deurenberg-Yap M, Ling A, Naidu RS, Ng SA., editors. Evaluating national nutrition promotion programs in Singapore. 135th APHA Annual Meeting and Exposition; 2007 Nov 3-7; Washington, D.C., USA. Washington, D.C.: American Public Health Association; 2007 Nov.
71. Lee M, Kim MK, Kim SM, Park H, Park CG, Park HK. Gender-based differences on the association between salt-sensitive genes and obesity in Korean children aged between 8 and 9 years. PLoS One 2015;10:e0120111.

72. Chung S, Kim YJ, Yang SJ, Lee Y, Lee M. Nutrigenomic functions of PPARs in obesogenic environments. PPAR Res 2016;2016: 4794576.

73. Petrosino JF. The microbiome in precision medicine: the way forward. Genome Med 2018;10:12.

74. Lee Y, Cha YS, Park Y, Lee M. PPARy2 C1431T polymorphism interacts with the antiobesogenic effects of Kochujang, a Korean fermented, soybean-based red pepper paste, in overweight/obese subjects: a 12-week, double-blind randomized clinical trial. J Med Food 2017;20:610-7.

75. International Union of Nutritional Sciences (AT). The global challenge of obesity and the international obesity task force [Internet]. Vienna: International Union of Nutritional Sciences; 2015 [cited 2015 July 23]. Available from: http://www.iuns.org/resources/ the-global-challenge-of-obesity-and-the-international-obesity-task-f orce/.

76. Leeman J, Sommers J, Leung MM, Ammerman A. Disseminating evidence from research and practice: a model for selecting evidence to guide obesity prevention. J Public Health Manag Pract 2011;17: $133-40$. 